dr. Sonja Kump znanstvena sodelavka na Inštitutu za družbene vede

\title{
PONUDBA IN KAKOVOST
} VISOKOŠOLSKEGA IZOBRAŽEVANJA ODRASLIH

\section{Visokošolsko izobraževanje odraslih postaja imperativ družbenega razvoja}

\begin{abstract}
V
razvitih državah število odraslih študentov v visokem šolstvu narašča in ponekod že presega delež rednih študentov, ki študij nadaljujejo neposredno po končani srednji šoli. Čeprav so visokošolsko izobraževanje odraslih dolgo časa obravnavali posebej in kot različno $\mathrm{v}$ primerjavi s tradicionalnim visokošolskim izobraževanjem, ki je bilo namenjeno selekcionirani populaciji mladih, se razmerje med visokim šolstvom, odraslimi in širšo družbo spreminja. Zaradi velikih družbenih
\end{abstract}

Odpiranje visokega šolstva vsem socialnim slojem in vsem starostnim kategorijam prebivalstva je posledica vladne politike, povezane $z$ enakimi možnostmi za izobraževanje tistih, ki niso nadaljevali začetnega izobraževanja zaradi ekonomskih razlogov ali drugih življenskih okoliščin. Vlade se namreč zavedajo, da za uspešno gospodarstvo in tekmovalnost na svetovnem trgu potrebujejo čedalje več visokošolskih diplonantov.

in tehnoloških sprememb postaja začetno izobraževanje in formalna izobrazba le podlaga nadaljnjega učenja in specializacije. Da bi lahko na novo oblikovali ali modificirali svoje poklicne vloge, potrebujejo odrasli novo disciplinarno ali interdisciplinarno znanje. Tako se kljub številnim oviram čedalje več odraslih, zlasti v razvitih državah, občasno ali večkrat vključuje v visokošolsko izobraževanje. Večji priliv odraslih v visoko šolstvo je povezan tudi s širšimi dejavniki, kot so na primer demografski, socialni, gospodarski in tehnološki.

Visokošolske institucije so zaradi nižje stopnje natalitete $\mathrm{v}$ tehnološko razvitih družbah, kjer se zmanjšuje povpraševanje tradicionalnih (mladih) kandidatov po visokošolskem študiju, čedalje bolj pripravljene namenjati čas in sredstva izobraževanju odraslih. Potrebe po visokošolsko izobraženih strokovnjakih in novem specializiranem znanju naraščajo tudi zaradi revolucionarnega razvoja tehnologij, zlasti računalniške in elektronske informacijske tehnologije. Prilagajanje novim tehnološkim spremembam zahteva drugačno učenje in prilagajanje odraslih.

Visokošolsko izobraževanje odraslih postaja imperativ družbenega razvoja, ki pomeni povezovanje individualnih potreb po učenju, gospodarskih potreb po tehnološko usposobljenih kadrih in družbenih potreb po bolj izobraženih državljanih. Številne in različne potrebe pa narekujejo korenito spremembo vloge in poslanstva visokošolskih institucij, zlasti tradicionalnih univerz.

\section{RAZVOJ VISOKEGA ŠOLSTVA IN NOVE PRIORITETE}

Visokošolske institucije so odprle odraslim svoja vrata bolj na široko že $\mathrm{v}$ šestdesetih letih, ko so naraščale družbene potrebe po diplomantih in zahteve po prilagajanju visokošolskega izobraževanja poklicnim in praktičnim potrebam razvite industrijske družbe. Ideološki koncept države blaginje je bil podlaga družbenih pritiskov, s katerimi so se srečevale tedanje univerze. Pomagale naj bi pri razvoju in krepitvi konkurenčnosti narodnega gospodarstva in hkrati omogočale študij širokim socialnim slojem.

Politika izenačevanja izobraževalnih možnosti je nenehno širila število študijskih mest. Hitro zastarevanje znanja je zahtevalo prožnost $\mathrm{v}$ poučevanju in usklajevanje študijskih programov $\mathrm{z}$ zahtevami sodobne poklicne 
prakse. Čedalje bolj je postajalo jasno, da univerze niso dovolj prilagojene, prav tako pa tudi ne ustrezno vodene, da bi lahko zadovoljevale naraščajoče zunanje potrebe. Ker niso zmogle zadovoljevati čedalje večjih potreb zlasti po tehnično usposobljenih strokovnjakih in hkrati ohranjati akademsko raven študija, se je povečevala potreba po njihovi reorganizaciji. Temu je ob koncu šestdesetih let sledila institucionalna diferenciacija visokega šolstva z razvojem alternativnega, neuniverzitetnega sektorja visokega šolstva. To so bile izobraževalne institucije s prožnimi oblikami študijskih programov (npr. izredni študij in nadaljevalno izobraževanje), ki so bile prilagojene odraslim študentom. Funkcije alternativnega visokošolskega sektorja naj bi bile predvsem »ekstrinzične«, to pomeni izobraževanje dejansko usposobljenih diplomantov za potrebe nacionalnega gospodarstva in pospeševanje socialne mobilnosti. $\mathrm{V}$ nekaterih državah so ustanovitev neuniverzitetnih sektorjev visokega šolstva zagovarjali kot zaščito tradicije in avtonomije univerz.

Vlade so bile prepričane o ekonomskih, političnih in ideoloških učinkih izobraževanja, zato so izdatno financirale visokošolsko dejavnost. $\mathrm{V}$ osemdesetih, zlasti pa $\mathrm{v}$ devetdesetih, letih je bilo konec ekonomske rasti. Zaradi krčenja vladnih subvencij so tudi visokošolske institucije občutile ekonomske pritiske recesije. Vrstile so se redukcije javne porabe, strategija privatizacije in uveljavljanje tržnih načel. Takratna kriza visokega šolstva je povezana s proračunsko krizo, skratka, s finančnim preživetjem. Univerze morajo upoštevati naraščajoče število uporabnikov in

Nestabilno okolje in tekmovalnost med visokošolskimi institucijami odločlno spreminjata tradicionalno vlogo in funkcijo univerz, ki so se iz elitnih ustanov spremenile $\mathrm{V}$ množične ustanove. $\mathrm{V}$ zdajs̆nịh razmerah, ko izgubljajo monopol nad visokošolskim izobraževanjem, so se prisiljene, že zato, da lahko preživijo, prilagajati zunanjemu svetu. Sočasno $z$ deregulacijo visokega šolstva na univerzah uvajajo številne mehanizme za ocenjevanje in zagotavlianje kakovosti akademskega dela, ki postaja čedalje boli raznovrstno, hkrati pa se nenehno povečuje tudi obseg tega dela. različne zahteve, ki se izražajo $\mathrm{v}$ potrebah gospodarstva, lokalnih skupnosti in vse bolj heterogene populacije študentov. Na množičnih univerzah ne prevladujejo več mladi študenti, ki izhajajo iz višjih socialnih slojev in nadaljujejo študij z jasnimi akademskimi cilji neposredno po končani gimnaziji. $\mathrm{V}$ visokem šolstvu poteka tiha revolucija. Nekoč je bilo osredotočeno predvsem na predmet študija, danes pa se osredotoča na študenta, njegove potrebe in interese. Povečan vpis starejših študentov $\mathrm{z}$ bogatimi strokovnimi in drugimi življenjskimi izkušnjami spreminja razmerja med odraslimi in univerzami, ki postopoma postajajo prožnejše in na splošDanašnji študenti se med seboj zelo razlikujejo: po spolu, starosti, socialnem izvoru in tudi po poklicnih načrtih ter motivaciji za študij.

\section{PONUDBA VISOKOŠOLSKEGA IZOBRAŽEVANJA ZA ODRASLE}

Pregled visokošolskega izobraževanja odraslih v razvitih državah pokaže, da so modeli »odpiranja visokega šolstva odraslim « različni po svoji funkciji in obliki. Vsem pa je skupno naraščanje števila odraslih študentov in širjenje akademskih ter specializiranih programov, namenjenih posebej odraslim.

Načini, kako se visoko šolstvo odziva na potrebe po izobraževanju odraslih, so odvisni od zgodovinskega razvoja visokošolskih institucij, pa tudi od političnih, gospodarskih in kulturnih možnosti, v katerih delujejo. Med državami in institucijami visokega šolstva so velike razlike glede fleksibilnih možnosti za odrasle, kot so na primer vpisna merila, alternativna programska ponudba ali načini študija. Kljub številnim razlikam in nacionalnim posebnostim pa $\mathrm{v}$ svetu prevladujejo tri poglavitne vrste ponudbe visokošolskega izobraževanja, namenjene odraslim.

Prva vrsta ponudbe za visokošolski študij odraslih so različni stopenjski programi $\mathrm{v}$ sklopu tradicionalnih univerz in visokih strokovnih šol, ki se končujejo z akademskimi oziroma strokovnimi diplomami. Visokošolske institucije se $\mathrm{v}$ nekaterih državah $\mathrm{v}$ večjem, drugje pa $v$ manjšem obsegu prilagajajo odraslim z novimi oblikami storitev in novimi načini delovanja. Odraslim kandidatom po- 
nujajo alternativne, pripravljalne tečaje, $\mathrm{v}$ okviru katerih se usposabljajo za stopenjski študij. Pri vpisu jim priznajo delovne ali druge življenjske, neizobraževalne izkušnje. Organizirajo informativne in svetovalne službe za potrebe odraslih kandidatov in študentov ter posebne sprejemne izpite za odrasle, ki omogočajo alternativni vpis $\mathrm{v}$ visokem šolstvu. Na določenih institucijah ali v sklopu določenih študijskih programov organizirajo izredni stopenjski študij, skupaj z večernimi ali poletnimi šolami. Ponujajo modularno strukturo stopenjskega študija ter možnost prenašanja »točk « med različnimi študijskimi programi in institucijami. Skratka, visokošolske institucije odraslim prilagajajo vsebino, čas in organizacijo nekaterih konvencionalnih programov.

Dodatna možnost vključevanja odraslih v stopenjski študij je izobraževanje na odprtih univerzah, ki je dostopno vsem, ne glede na njihovo izobrazbo. Odprte univerze, ki so statusno izenačene s konvencionalnimi univerzami, pomenijo pomembno alternativo tradicionalnemu visokemu šolstvu, saj ponujajo akademske programe, ki so oblikovani predvsem za potrebe odraslih študentov, v nasprotju s programi, namenjenimi določeni starostni kategoriji. Programi so torej prilagojeni različnim življenjskim izkušnjam in okoliščinam odraslih študentov. Te alternativne visokošolske institucije so zelo prožne, omogočajo študij na daljavo $\mathrm{v}$ interdisciplinarnih študijskih programih, ki so strukturirani v modulih. Dopisni študij se dopolnjuje s sodobnimi komunikacijskimi pripomočki, ki so navadno nameščeni $\mathrm{v}$ študijskih središčih po državi, kjer $\mathrm{z}$ računalniki usklajujejo učne načrte in izpite. Britanska »odprta univerza « (ustanovljena leta 1969) je vzorec za večino odprtih univerz z izobraževanjem na daljavo, ki se širijo po vsem svetu.

Druga vrsta ponudbe visokošolskega izobraževanja, namenjene odraslim, je tako imenovano nadaljevalno izobraževanje. Visokošolske institucije organizirajo krajše programe za osvežitev, izpopolnjevanje in posodabljanje poklicnega znanja in spretnosti tistih, ki so že končali visokošolski študij. Programi nadaljevalnega izobraževanja so posebej načrtovane in izpeljane oblike izobraževanja za pridobivanje dodatnega strokovnega ali splošnega znanja, ki ga zahteva strokovno de- lo. Kandidati po končanem programu opravljajo izpit, dobijo potrdilo ali pa tudi ne.

Organizacija nadaljevalnega izobraževanja je po državah zelo različna. V nekaterih državah je organizirano $v$ posebnih enotah za nadaljevalno izobraževanje, ki delujejo $\mathrm{v}$ okviru univerz in so sestavni del univerzitetnega sistema. Tako ima na primer v Franciji in na Finskem vsaka univerza svojo enoto za nadaljevalno izobraževanje s stalno zaposlenim osebjem. V Veliki Britaniji imajo univerze običajno dve ločeni administrativni enoti: ena ureja zadeve $\mathrm{v}$ zvezi $\mathrm{z}$ izrednim stopenjskim študijem, druga pa se ukvarja $z$ izpopolnjevanjem in posodabljanjem strokovnega znanja. Za nadaljevalno izobraževanje so značilne poslovna in tekmovalna usmerjenost ter osredotočenost $\mathrm{v}$ zadovoljevanje lokalnih potreb.

Tudi ponudba nadaljevalnega izobraževanja je zelo raznolika. Interesi vlade in delodajalcev ter motivi večine morebitnih udeležencev nadaljevalnega izobraževanja so osredotočeni predvsem na poklicno usmerjeno ponudbo visokošolskih institucij. Zato je zlasti na lokalni ravni čedalje več visokošolskih institucij, ki z delodajalci sklepajo dogovore o različnih programih usposabljanja, skupaj s posebnimi »internimi (in-service) programi, ki so prilagojeni razvojnim spremembam posameznih podjetij. Nekatere univerze, na primer finske, $\mathrm{z}$ državno podporo organizirajo programe za brezposelne diplomante. Toda vlade $\mathrm{v}$ večini držav omejujejo sredstva za nadaljevalno izobraževanje in $\mathrm{s}$ tem silijo visokošolske institucije $\mathrm{v}$ iskanje dodatnih sredstev. Zaradi tega postaja ponudba nadaljevalnega izobraževanja vse bolj tržno usmerjena. To pomeni, da se visokošolske institucije usmerjajo v zunanje okolje in spreminjajo način dela. Tržnost jih prisili $k$ večji odprtosti in komunikaciji z zunanjim svetom, še zlasti zato, ker je visokošolska ponudba nadaljnjega izobraževanja slabo poznana in skromno artikulirana. Tradicionalne univerze zaradi svoje akademske naravnanosti in neustreznega vodenja ter upravljanja pogosto ne želijo ali pa preprosto niso sposobne zadovoljevati potreb delodajalcev v zvezi z nadaljevalnim izobraževanjem. S tem se odrekajo dodatnim virom financiranja, delodajalci pa sklepajo pogodbe s številnimi zasebniki, ki so do delodajalcev veliko bolj ustrežljivi in prilagodljivi. Tretja vrsta visokošolske ponudbe izobraže- 
vanja za odrasle je splošno ali tudi »liberalno" izobraževanje v obliki neformalnih (nešolskih) programov, predvsem humanističnih in družboslovnih vsebin, za širšo javnost. To so splošnoizobraževalni programi, tečaji, svobodne ali odprte katedre, javna predavanja, ki obravnavajo aktualna družbena, politična, kulturna in osebna vprašanja.

Ponudba visokošolskega splošnega izobraževanja izvira iz »moralne obveze" britanskih univerzitetnih dostojanstvenikov iz Oxforda in Cambridgea iz 19. stoletja. Nekateri tedanji univerzitetni profesorji so bili namreč ogorčeni nad tem, da ima le elita dostop do znanja. Zato so zunaj univerzitetnih zidov začeli predavati in širiti tedanjo elitno kulturo v korist samoizpopolnjevanja posameznikov. Predvsem $z$ vsebinami iz angleške zgodovine in literature so skušali razvijati in spodbujati višjo izobraženost ter kulturo množic. Leta 1870 so organizirali posebne razširjene programe (university extension courses), ki so jih izvajali v sklopu dislociranih oddelkov univerz. Zgodovinski viri navajajo, da je samo v letu 1890 te programe obiskovalo več kot 50.000 starejših slušateljev.

V nekaterih državah odprto splošno izobraževanje na univerzah ponovno oživlja. Univerze zaradi velikega povpraševanja po tej vr-

Tradicija splošnega izobraževanja kot kulturne funkcije in moralne obveze univerz je $\mathrm{v}$ zadnjih desetletih oslabela. Koncept odraslih se je namreč premaknil od obravnavanja odraslega kot osebnosti s kulturnimi in družbenimi potrebami $k$ obravnavanju odraslega kot ekonomskega bitja, s potrebami, ki so povezane z njegovim delom. Izobraževanje in usposabljanje odraslih zato vsebinsko večinsko določajo trżne vrednote in ekonomska naravnanost $v$ družbi. Predavanja splošnih vsebin, ki so dostopna vsem in so śe vedno del univerzitetne ponudbe za siršo družbo, imajo marginalni pomen. Na njh predavajo najvećkrat honorarni predavatelii. Na univerzah imajo njhovo delo običajno za nepomembno in neugledne. Razloge za takšne razmere ne moremo iskati le na univerzah, ampak tudi $\mathrm{v}$ družbi, kjer za programe splośnega izobraževanja odraslih ni veliko zanimanja. sti izobraževanja širijo ponudbo splošnih programov. Vsebine programov so veliko bolj raznovrstne, kot so bile nekoč. Obravnavajo različne družbene in osebne probleme, probleme družinskega življenja, zdravstvene probleme, civilna in politična vprašanja.

Ponudba visokošolskega izobraževanja odraslih v Sloveniji je še vedno dokaj skromna in slabo poznana. Prva vrsta ponudbe, to je izredno izobraževanje za različne stopenjske študije, je vsako leto predstavljena $\mathrm{v}$ skupnem razpisu za vpis na vse visokošolske zavode $\mathrm{v}$ državi, ki ga objavlja Ministrstvo za šolstvo in šport. Toda raznovrstnost ponudbe »druge priložnosti« za vse tiste, ki iz različnih vzrokov niso nadaljevali študija, se v primerjavi s preteklimi leti celo zmanjšuje. Prav tako pa je opazno pomanjkanje alternativnih struktur in fleksibilnih študijskih programov, ki bi bili resnično prilagojeni odraslim. Ponudba nadaljevalnega izobraževanja ni sistematična in ostaja v pristojnosti posameznih visokošolskih zavodov oziroma oddelkov. Najmanj je razvita ponudba splošnega (neformalnega) izobraževanja. Predavanja nepoklicnih vsebin za širšo javnost so nenačrtovana in le občasna.

\section{NADZOR NAD KAKOVOSTIO V VISOKEM ŠOLSTVU}

$\mathrm{V}$ razvitem svetu se kakovost izobraževanja odraslih preverja $\mathrm{z}$ različnimi mehanizmi $\mathrm{v}$ okviru ocenjevanja celotne visokošolske dejavnosti. Čedalje večje zanimanje vlad in javnosti za kakovost visokega šolstva je posledica ekspanzije in diverzifikacije visokošolskih sistemov, konkurenčnosti nacionalnih gospodarstev, splošnih teženj po decentralizaciji in okrepljeni institucionalni avtonomiji, nastajanja novih zasebnih visokošolskih institucij in internacionalizacije visokega šolstva.

$\mathrm{V}$ preteklosti je javnost zaupala univerzam, da so same nadzorovale svoje delo, zaupala je $\mathrm{v}$ kompetentnost akademikov, saj naj bi bili intrinzično motivirani za to, da vzdržujejo kakovost svojega dela in rezultate tega dela, zaupala je torej $v$ akademske dogovore o nadzoru in vzdrževanju kakovosti. Kakovost univerz je bila nekaj samoumevnega. Danes to ni tako. Zaradi temeljnih sprememb v visoko- 
šolskih sistemih, kjer lahko opazimo premike od elitnega $\mathrm{k}$ množičnemu izobraževanju, od kulturnega aparata družbe $\mathrm{k}$ ekonomskemu aparatu, od izobraževanja kot osebne in statusne koristi k širši družbeni koristi, od intrinzičnih lastnosti $\mathrm{k}$ instrumentalnim koristim; zaradi ekonomskega preživetja med razvitimi svetovnimi trgi se je še posebej omajalo zaupanje $\mathrm{v}$ notranje akademske mehanizme nadzora kakovosti.

Eden izmed razlogov, ki pojasnjujejo povečano pozornost, namenjeno problematiki kakovostnega visokega šolstva, je širjenje visokošolskih sistemov. Zaradi kvantitativne rasti in diverzifikacije visokošolskih sistemov naraščajo dvomi o kakovosti »izdelkov « visokošolske dejavnosti, znotraj in tudi zunaj visokošolskih institucij.

Zaradi izrednega porasta števila študentov, nastajanja novih študijskih disciplin in razraščanja specializacij ter ustanavljanja novih oddelkov in celotnih institucij se zaostrujejo vprašanja o deležu in razporeditvi javne porabe za visoko šolstvo. Že v osemdesetih, zlasti

V razvitem svetu zunanjo, državno kontrolo in regulacijo visokega šlstva čedalje bolj nadomeščajo s sistemon zagotavljanja kakovosti, ki je kombinacija zunanjega in notranjega nadzora nad kakevostjo. Ti sistemi, ki so ih razvili v devetdesetih letih, naj bi bili sprejemljivi tako za vlade kot za visokošolske institucije.

pa $\mathrm{v}$ devetdesetih, letih so vlade začele omejevati porabo $\mathrm{v}$ družbenih službah in iskati poti, da bi za manj dobile boljše. Hkrati s krčenjem proračunskih sredstev pa vlade razglašajo pomen visokega šolstva pri krepitvi konkurenčnosti nacionalnih gospodarstev in zahtevajo jasno opredelitev družbene koristnosti visokega šolstva. Zato morajo visokošolske institucije širši družbi nenehno pojasnjevati, kaj delajo in kako dobro to počnejo.

Tudi uporabniki zahtevajo in pričakujejo čedalje več. Povečujejo se pritiski na visokošolske institucije, naj predstavijo kakovost svoje ponudbe tistim, ki jo plačujejo (vladi, davkoplačevalcem), in tistim, ki jo sprejemajo neposredno (študentom) oziroma posredno (delodajalci in družba na splošno).

Poglavitni namen zunanjega nadzora je odgovornost visokega šolstva do širše družbe. Odgovornost za kakovost pomeni, da imajo vi- lahko širši javnosti ponazorijo doseganje svojih ciljev. Poleg odgovornosti so še drugi nameni, kot so na primer načrtovanje visokega šolstva, vpogled v kakovost, vrednost za denar, transparentnost in mednarodna kredibilnost visokega šolstva.

Temeljni cilj notranjega nadzora nad kakovostjo je izpopolnjevanje kakovosti. Poleg tega lahko notranje zagotavljanje kakovosti prispeva $\mathrm{k}$ boljšemu samospoznavanju, samorazumevanju in samoučenju ter služi kot pomoč pri samoregulaciji visokošolske institucije.

Učinkovitost notranjega zagotavljanja kakovosti ni odvisna od vrste in števila teh mehanizmov, ampak predvsem od razvite kulture kakovosti med vsemi člani akademske skupnosti. Toda spreminjanje kulture je počasen in zapleten proces, ki ga ni dobro pospeševati. Spreminjanje kulture zahteva postopno spreminjanje vedenja in delovnih metod, predvsem pa spremembo načina vodenja in upravljanja institucije. Odločilni dejavnik za zagotavljanje kakovosti je osebna motiviranost, ki ima tudi pri uvajanju novosti oziroma pri posodabljanju študija najpomembnejšo vlogo.

Dober sistem notranje skrbi za kakovost temelji na samoevalvaciji, ki postane del rednega spremljanja in pregleda študijskih programov in drugih dejavnosti, povezanih z izobraževalnim delom. Visokošolske institucije lahko kakovost svojega dela vzdržujejo in izpopolnjujejo na osnovi vodenja evidenc o različnih vidikih izobraževanja. To pa pomeni zbiranje različnih informacij (kot so npr. podatki o študijskem napredovanju in o študijski uspešnosti, osipu, diplomantih in njihovi zaposlenosti itd.). Visokošolske institucije lahko šele na podlagi redno vodene evidence ocenjujejo izobraževalni proces, identificirajo problematična področja in pripravljajo ukrepe za reševanje problemov. Tako lahko kadarkoli ugotavljajo, ali se približujejo ciljem, preverjajo svoj utrip in ukrepajo takoj, ko je treba.

\section{ZAGOTAVLJANJE KAKOVOSTI SLOVENSKEGA VISOKEGA ŠOLSTVA}

Zunanji nadzor nad kakovostjo visokošolskih institucij bo prevzela Komisija za kvaliteto visokega šolstva, ki so jo pred kratkim 
ustanovili vsi visokošolski zavodi v Sloveniji. Strokovne osnove za začetek dela komisije nastajajo v sklopu projekta Evalvacija visokega šolstva, ki ga financirata Ministrstvo za znanost in tehnologijo ter Ministrstvo za šolstvo in šport. Cilj projekta je oblikovanje, implementacija in nadaljnje razvijanje modela za zagotavljanje kakovosti slovenskega visokega šolstva, ki bi vključeval metodo samoevalvacije, kolegialne kontrole in institucionalne revizije. Model naj bi bil zasnovan v skladu $\mathrm{z}$ dolgoletnimi evalvacijskimi izkušnjami $\mathrm{v}$ tujini, hkrati pa bi upošteval nacionalno ureditev visokošolskega sistema, njegove namene, potrebe, politične, gospodarske in kulturne okoliščine, v katerih deluje. Pri takšnem modelu bi zunanja evalvacija kakovosti pomenila razširjeno skrb za notranji nadzor kakovosti visokošolskih institucij. Bistvena povezava zunanjega ocenjevanja in notranjega zagotavljanja kakovosti bi bila samoevalvacija, ki bi poleg samoocenjevanja vključevala ocene tujih predmetnih izvedencev in povratne informacije tako imenovanih uporabnikov, kot so študenti, diplomanti, delodajalci in strokovna združenja.

V letu 1996 se je začela eksperimentalna faza samoevalvacij, ki poteka na podlagi vzorca študijskih programov v sklopu posameznih oddelkov, kateder oziroma visokošolskih institucij. Na osnovi spremljanja prvih samoevalvacijskih izkušenj bodo raziskovalci naprej razvijali metodološko evalvacijsko orodje in postopke. Na tej podlagi bo mogoč postopen prehod na samoevalvacijo, ki naj bi postala dejavnik redne dejavnosti visokošolskih institucij, v kasnejših letih pa se bo nadgrajevala v celovit sistem.

\section{KAKOVOST VISOKOŠOLSKEGA IZOBRAŽEVANIA ODRASLIH}

V zahodnoevropskih državah je uvajanje mehanizmov in postopkov zagotavljanja in preverjanja kakovosti v visokem šolstvu v devetdesetih letih prednostna naloga. $Z$ razvijanjem teh mehanizmov in postopkov je posebna pozornost namenjena evalvaciji in spodbujanju kakovosti izobraževanja odraslih.

Slovenske visokošolske institucije naj bi $\mathrm{v}$ predvidenem sistemu za zagotavljanje kakovosti posebno pozornost posvetile tudi kakovosti visokošolskega izobraževanja odraslih.
Samoevalvacije, ki bodo potekale na ravni študijskega programa v okviru oddelkov, na ravni fakultet, akademij in visokih strokovnih šol ter na ravni univerze, naj bi vključevale analizo in ovrednotenje vprašanj, kot so:

- Institucionalna organiziranost in politika izobraževanja odraslih.

- Ugotavljanje individualnih in širših družbenih potreb po posameznih vrstah izobraževanja odraslih (stopenjski študij, nadaljevalno strokovno usposabljanje, javna predavanja s splošnimi vsebinami).

- Cilji študijskega programa: na primer usklajenost $\mathrm{s}$ programskimi cilji; usklajenost vsebine programa; seznanjenost odraslih študentov in njihovih učiteljev $s$ programskimi cilji itd.

- Organizacijska in vsebinska struktura programa: na primer uravnoteženost splošnega in specialističnega izobraževanja; strokovna konsistentnost in sodobnost vsebin programa ter razmerje med teoretičnim znanjem in praktičnim usposabljanjem; povezanost $\mathrm{z}$ drugi-
Z novo visokošolsko zakonodajo je tudi $v$ Sloveniji opredeliena sistemska skrb za kakovost visokega šolstva. mi programi; mednarodna primerljivost, prilagajanje študijskih programov spremenjeni študentski populaciji, kot so na primer novi programi, ki so prilagojeni netradicionalnim študentom; razvijanje posebnih študijskih programov za posamezne ciljne skupine odraslih, kot so lahko na primer brezposelni diplomanti); uvajanje modularnih programskih struktur in možnost zbiranja ter prenašanja »točk « med različnimi visokošolskimi institucijami itd.

- Obveščenost o možnostih za izobraževanje odraslih: na primer priprava posebnih informativnih brošur, ki bi vključevale podatke o vseh vrstah, oblikah in vsebinah visokošolskega izobraževanja in usposabljanja odraslih.

- Vpisna politika: na primer razvijanje raznih oblik predhodne pomoči odraslim kandidatom za študij, kot so pripravljalni tečaji, ločeni vpisni pogoji za odrasle kandidate, posebni vpisni obrazci in postopki, ki bi bili prilagojeni odraslim udeležencem visokošolskega izobraževanja; priznavanje in akreditacija predhodnega učenja, delovnih in drugih življenjskih izkušenj. 
- Udeležba odraslih študentov: na primer podatki o številu odraslih študentov, njihov delež glede na celotno število študentov, podatki o starosti, spolu, socialnem izvoru in izobrazbi odraslih študentov itd.

- Svetovanje in pomoč študentom: na primer razne oblike pomoči odraslim študentom: razvijanje individualnega usmerjanja in svetovanja odraslih kandidatov ter odraslih študentov; svetovanje pri izbiri programa; uvajanje v študij, seznanjanje odraslih študentov z različnimi učnimi metodami in načrti iskanja zaposlitve; pomoč odraslim študentom pri študijskih in osebnih težavah; razvijanje raznih oblik samopomoči odraslih študentov; postopki za uveljavljanje varstva pravic odraslih študentov itd.

- Visokošolski učitelji in drugo osebje: na primer didaktična in andragoška usposobljenost visokošolskih učiteljev za poučevanje in delo z odraslimi; imenovanje, napredovanje, obnova, novačenje, skrb za nenehni strokovni razvoj in izpopolnjevanje učiteljev ter drugih visokošolskih delavcev, ki se posebej ukvarjajo z odraslimi itd.

- Prostori, oprema in študijski pripomočki: na primer prostorske razmere in opremljenost; študijski prostori; primernost in dostopnost informacijske tehnologije ter drugih učnih pripomočkov in opreme, potrebne za izvajanje študijskih programov za odrasle; računalniki in druga informacijska tehnologija, ki je dostopna odraslim študentom itd.

- Viri financiranja: na primer kolikšen delež sredstev prispevajo odrasli študenti, koliko sredstev za izvedbo programa prispeva država in kolikšen delež je zagotovljen s posebnimi pogodbami, ki jih visokošolska institucija sklepa z delodajalci oziroma podjetji.

- Poučevanje, učenje in preverjanje znanja: razvijanje novih pristopov $\mathrm{v}$ poučevanju in učenju, ki spodbujajo prožnost na vseh stopnjah izobraževalnega procesa: od oblikovanja programa do metod ocenjevanja; razmerje med različnimi metodami poučevanja; doseganje ciljev poučevanja; znanje in spretnosti študentov (skrb za njihov kognitivni, strokovni, intelektualni in osebni razvoj); razvoj samostojnega učenja; uvajanje metod učenja na daljavo itd.

- Diplomanti: na primer raven znanja in spretnosti diplomantov; možnosti na trgu de- lovne sile; uspešnost diplomantov pri pridobivanju zaposlitve; nadaljnje izpopolnjevanje diplomantov; relevantnost programa za poklicno kariero diplomantov itd.

- Zunanje razmere: na primer usklajenost programske ponudbe med različnimi institucijami, ki se ukvarjajo z izobraževanjem odraslih študentov; povezanost študijskega programa $\mathrm{z}$ industrijo, poslovnim svetom, javnimi službami, zasebnim sektorjem ter strokovnimi združenji itd.

- Notranje zagotavljanje in izpopolnjevanje kakovosti: na primer sprotno in sistematično spremljanje in ocenjevanje študijskega programa; evidenca o notranjem zagotavljanju kakovosti (npr. poročilo o samoevalvaciji na ravni študijskega programa, mehanizmi povratnih informacij, kot so mnenje odraslih študentov ali delodajalcev o programu študija) in povezava s širšim, institucionalnim zagotavljanjem kakovosti; sistem sprotnega, individualnega spremljanja študijske uspešnosti odraslih študentov; načrti in prioritete za vzdrževanje in povečanje kakovosti itd.

Samoevalvacijsko poročilo naj bi poleg ocene prednosti in slabosti študijskega programa (ki je izdelano na osnovi opisa in kritične analize posameznih poglavitnih vidikov študijskega programa) vsebovalo tudi predloge in ukrepe za nadaljnje posodabljanje in izpopolnjevanje kakovosti izobraževanja odraslih. S samoevalvacijo bodo visokošolske institucije lahko oblikovale prožnejšo politiko izobraževanja odraslih, saj bodo ugotavljale prednosti in pomanjkljivosti programa, ki se ga udeležujejo odrasli. S sistematično evalvacijo celotnega visokega šolstva bodo dobili tudi "uporabniki « ustrezne informacije o ponudbi in možnostih odraslih v visokem šolstvu.

\section{SKLEPNE MISLI}

Ker so stare univerzitetne strukture zelo močne, se novosti na univerzah le stežka uveljavljajo. Njihova tradicionalna značilnost je namreč odpor do sprememb. Čeprav so priča velikim zunanjim potrebam po izobraževanju odraslih, med njimi prevladuje prepričanje, da je širjenje visokošolskega izobraževanja odraslih nekonsistentno z veljavnimi vrednotami, izkušnjami in potrebami univerze. $\mathrm{Na}$ mnogih univerzah tudi upajo in celo verjamejo, da so v visokem šolstvu pojmi, kot je na 
primer odgovornost, kakovost ali revizija, le modne muhe. Toda to je prazno upanje. Univerze bodo preživele le, če bodo delovale kot dostopni in transparentni sistemi. Ponekod se tega že zavedajo in zato širijo svoje poslanstvo s konceptom vseživljenjskega izobraževanja in učeče se institucije. Toda še vedno je veliko univerz, zlasti tradicionalnih, ki vztrajajo znotraj svojih slonokoščenih zidov in razglašajo, da je njihovo najpomembnejše poslanstvo ohranjanje in prenašanje vednosti ter učenosti na izbrane predstavnike mlajših generacij.

\section{LITERATURA}

Bourner, T., Reynolds, A., Hamed, M., Barnett, R. (1991). Part-time Students and Their Experience of Higher Education. Buckingham: SRHE \& Open University Press.

Davies, P. (Ed.) (1995). Adults in Higher Education. International Perspectives on Access and Participation. London: Jessica Kingsley Publishers.

Duke, C. (1992). The Learning University? Towards a New Paradigm?. Buckingham: SRHE \& Open University Press.
Enckevort, G. V., Harry, K., Morin, P., Schütze, G. (Eds.) (1986). Distance Higher Education and the Adult Learner. Assen/Maastricht: Dutch Open University, Heerlen Van Gorcum.

Jarvis, P. (1993). The University and the Adult in Late Modernity. International Journal of University Adult Education, 3, str. 70-90.

Kakovost visokega šolstva. (1994). Tematska številka Novosti CRU, št. 5-6, Ljubljana: Univerza v Ljubljani, Center za razvoj univrrze.

Kasworm, C. E. (1993). Adult higher education from an international perspective. Higher Education, 25, str. 411-423.

Kivinen, O., Rinne, R., Hypponen, K. (1992). New clients for higher education and the problem of closed university. Higher Education Management, 1, str. 28-42.

Kump, S. (1994). Akademska kultura. Ljubljana: Znanstveno in publicistično središče.

Kump, S. (1995). Zagotavljanje kakovosti slovenskega visokega šolstva. Raziskovalec, št. 4, str. 9-14.

Kump, S. (1995). Samoevalvacija v visokem šolstvu. Ljubljana: Andragoški center Slovenije.

Schütze, H. G. (1991). Is the Academy Ready for Adult Students? Higher Education in Europe, 1, str. 13-25.

Titmus, C., Knoll, J. H., Wittpoth, J. (1995). Continuing Education in Higher Education. Leeds: Study of Continuing Education Unit, University of Leeds.

Westerheijden, D. F., Brennan, J., Maassen, P. A. (Eds). (1994). Changing Contexts of Quality Assessment. Utrecht: Uitgeverij Lemma B. V. 